\title{
Telemetry System for Research Stratospheric Balloon
}

\author{
Pavel Puričer, Pavel Kováŕ, Jan Mikeš, Jakub Kákona \\ Faculty of Electrical Engineering FEE \\ The Czech Technical University in Prague CTU \\ Prague, Czech Republic \\ puricep@fel.cvut.cz
}

\begin{abstract}
The paper presents telemetry system for stratospheric balloon mission based on the UHF transceivers designed for Internet of Things. The system operates in $869.5 \mathrm{MHz}$ frequency band. The system uses very short packet without channel coding that can be successfully received and decoded under low signal to noise ratio. The modem sensitivity $-124 \mathrm{dBm}$ and the transmission power $25 \mathrm{dBm}$ can ensure reliable communication for distances longer than $100 \mathrm{~km}$ with omnidirectional antennas and $200 \mathrm{~km}$ with $10 \mathrm{dBi}$ ground station directional antenna. The telemetry system uses GFSK modulation of bit rate $1200 \mathrm{Bd}$ and is designed for a transmission of the balloon position and status.
\end{abstract}

Keywords-telemetry;
communication; UHF band

\section{INTRODUCTION}

One of the cost effective methods for investigation of the upper atmosphere and ionosphere is a use of ionospheric balloons. The presented telemetry system was developed for balloon experiments FIK organized by the Department of Radiation Dosimetry, Nuclear Physic Institute, The Czech Academy of Science with a cooperation of the Czech Technical University in Prague [1]. The aim of the FIK experiment is to study radiation in the upper atmosphere and stratosphere, to engage students of the Czech Technical University and other people to the research project, and to popularize science.

The mission of the balloon telemetry system is to transmit position and status information during the whole stratospheric flight and its safe recovery after landing.

The typical flight duration of the research stratospheric balloon is two hours, the balloon climbs to the altitude about $30 \mathrm{~km}$ MLS in which it bursts and the scientific instruments together with the balloon residue return on the parachute. The flight distance depends on the actual weather conditions and varies from tens to thousand kilometers.

\section{TEChNOLOGY SELECTION}

\section{A. Requirements}

The selection of the proper communication technology is critical as the communication is carried out on relatively long distance. In addition, the balloon transmitter must be light and must have low power consumption due to the weight restrictions. The telemetry system has to avoid adverse influences to operation of the sensitive scientific instruments in the balloon basket. The problem of the interference can be solved by proper electromagnetic shielding or by scheduling the operation of the scientific instruments with the telemetry system transmission. The high-level requirements on telemetry systems developed on the base of experiences with the previous balloon experiment FIK 2015 [1] are summarized in Tab. I.

TABLE I. TELEMETRY SySTEM HIGH LEVEL REQUIREMENTS

\begin{tabular}{|l|l|l|}
\hline \multicolumn{1}{|c|}{ Parameter } & \multicolumn{1}{|c|}{ Value } & \multicolumn{1}{c|}{ Note } \\
\hline Mode & Downlink & $\begin{array}{l}\text { Uplink is not necessarily as } \\
\text { balloon is uncontrolled }\end{array}$ \\
\hline Range & $\begin{array}{l}>200 \mathrm{~km} \\
\text { Tracking station } \\
\text { Search station }\end{array}$ \\
\hline Weight & $>200 \mathrm{~g}$ & $\begin{array}{l}\text { Modem, GPS receiver, } \\
\text { communication antenna, } \\
\text { GPS antenna, battery }\end{array}$ \\
\hline $\begin{array}{l}\text { Time of } \\
\text { operation }\end{array}$ & Position & $\begin{array}{l}\text { 1 hour - flight preparation } \\
\text { 2 hours - flight } \\
\text { 3 hours - search and rescue }\end{array}$ \\
\hline Telemetry data & $\begin{array}{l}\text { Time } \\
\text { Longitude } \\
\text { Altitude } \\
\text { UTC time } \\
\text { GPS status } \\
\text { Battery voltage } \\
\text { Modem temperature }\end{array}$ \\
\hline $\begin{array}{l}\text { Transmission } \\
\text { period }\end{array}$ & $10-60 \mathrm{~s}$ & $\begin{array}{l}\text { According the scientifical } \\
\text { instruments operation }\end{array}$ \\
\hline
\end{tabular}

\section{B. Mobile systems}

The utilization of the existing mobile systems is not possible in high altitudes. The base stations antenna radiation patterns are oriented to the users on the Earth surface [2]. In addition, the GSM and 3G timings advance [3] is set up to value to guarantee communication on distance $35 \mathrm{~km}$ maximally. The communication is synchronized by the base station. The blocking of the transmission during instruments measurement is problematic.

\section{Internet of Things}

The same problem is with long range Internet of Things (IoT) mobile systems like SIGFOXS or LoRa [4] as the base station antennas are not pointed upwards and therefore the service at high altitude is not available. On the other hand, the synchronization of the transmission with the measurement cycle of the scientific instruments is not a problem as the access to the radio channel is not regulated and it is random. 


\section{Satellite mobile systems}

The telemetry system can be realized by the satellite mobile systems like Iridium, Inmarsat or Thuraya, that have no problem with coverages of high altitudes in contrast of terrestrial mobile systems. The problems are higher purchase and operating cost. The systems implement TDMA controlled by the satellite, therefore the synchronization of the transmission is problematic as well.

\section{E. Proprietary communication system}

The next possibility is to adopt some suitable transceiver or data modem or to develop new original one according to the balloon mission requirements. Still, the operation of the transceiver on the particular frequency band has to comply with regulations and permission [6] of the Czech Telecommunication Office (CTU).

\section{TELEMETRY SyStEM ARCHITECTURE}

The conceptual design of the proposed stratospheric balloon telemetry systems comes from the communication system developed for the Lucky 7 CubeSat [5]. The communication system of Lucky 7 operates in amateur $70 \mathrm{~cm}$ frequency band and is designed on the base of Si4463 chip (Fig. 1.) [8] for low power communication. Chip is widely used for proprietary communication systems or in long range low-power IoT like SigFox. The communication system uses simple communication protocol based on the short fixed length packet of length 19 Bytes.

The chip contains all part for a realization of the low power low or medium bit rate VHF and UHF digital transceiver. It integrates low intermediated frequency reconfigurable receiver that is completely integrated in the chip, digital modulator, and power amplifier for the realization of the transceiver. The next important part is a reconfigurable digital modulator and demodulator and packet stack, scrambling, CRC etc. The communication with the processor runs on SPI bus.

Figure 1. Block diagram of Si4463

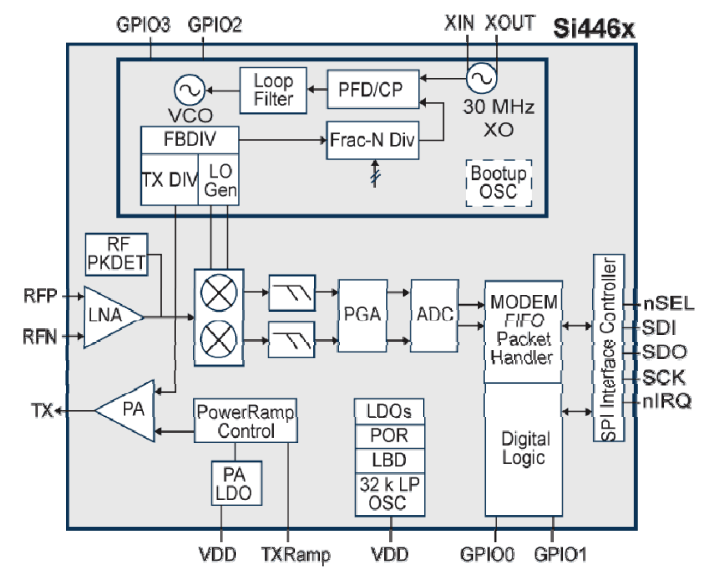

The chip can use cheap and low power consumption quartz oscillator instead of higher precision TCXO for carrier frequency generation and for frequency conversion. The frequency offsets synchronization circuit can at first run with much wider bandwidth than required for further high sensitivity data demodulation. After compensation of the actual frequency error, the bandwidth of the receiver is reduced.

The noise figure of the transceiver is about $11 \mathrm{~dB}$ as the transceiver was optimized for low power consumption instead of high sensitivity.

For the realization of the telemetry system, the radio modem operates on unlicensed frequency band $869.4 \div 869.65 \mathrm{MHz}$. The CTU regulation [6] permits maximal radiated power $500 \mathrm{~mW}$ and the transmitter can operate $10 \%$ of the time.

\section{A. Radio-modem}

The block diagram of the developed modem is in Fig. 2. The modem is equipped with the splitter for connection of the SDR receiver for processing of the ADS-B signals on frequency $1090 \mathrm{MHz}$. The modem integrates monolithic power amplifier for increasing the transmitted power, low noise amplifier for improvement of the noise figure. The next design provision for sensitivity improvement is to use high precise TCXO instead of quartz as the chip uses noncoherent data demodulator whose performance depends on the noise bandwidth.

The modem is controlled by Cortex 4 microcontroller that integrates interfaces for connection of the GPS receiver and other interfaces.

The modem and other blocks of the telemetry system are fed by the switched power supply. Each block like LNA, power amplifier, GPS, and transceiver chip can be switched off or disabled in order to minimize power consumption.

The firmware is programmed in $\mathrm{C}$ language. The real kernel RTOS is used for speedup and simplification of the firmware development.

The photo of realized radio modem is in Fig. 3.

\section{B. Telemetry system}

The telemetry system (Fig. 4) is designed as an modular independent system powered by the separate battery as the impact of the scientific instruments in the balloon basket to common power supply network is unpredictable. During the last balloon flight FIK 2015 , there occurred the problems with the power supply that were manifested by the fluctuation of the power level and the on-board instruments were reset several times.

Figure 2. Block diagram of modem

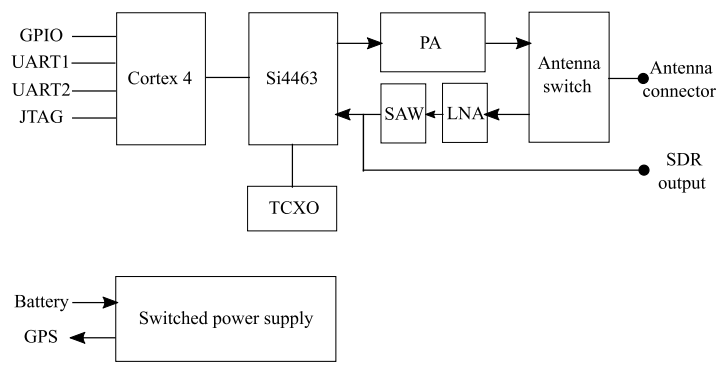


Figure 3. Radio modem

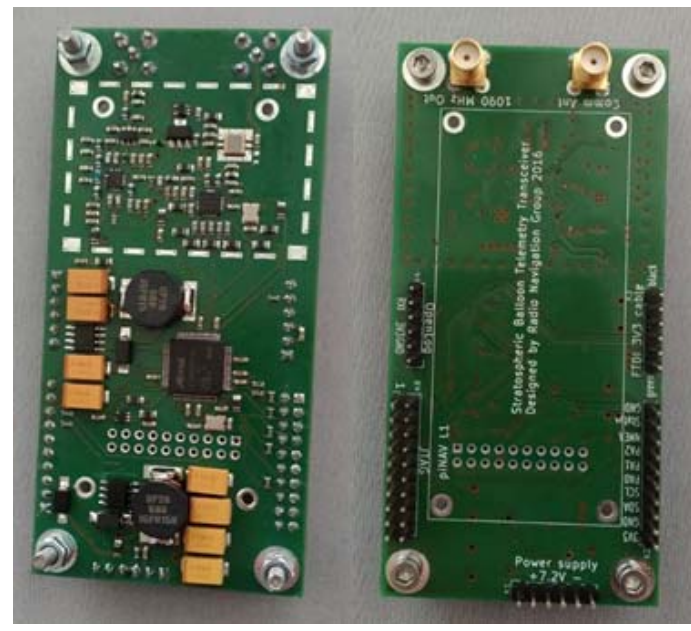

Figure 4. Block diagram of the balloon telemetry system

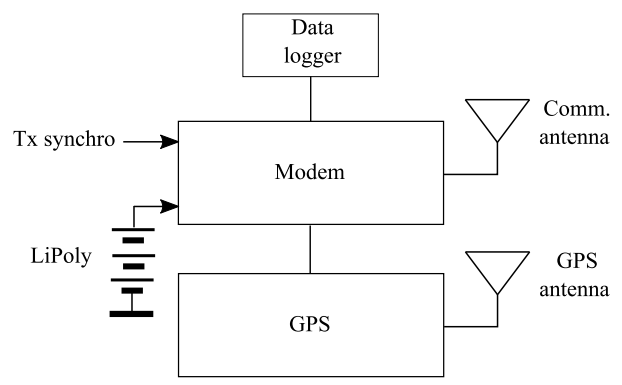

\section{TRANSMISSION FORMAT}

The telemetry system uses standard GPS receiver tested for high amplitude positioning. The receiver provides standard NMEA GGA message that transmits UTC time, geodetic coordinates, altitude, the number of tracked satellites, and horizontal dilution of precision. The NMEA sentence is not suitable for transmission via the low rate modem as it contains a lot of redundancy. Let us note that the NMEA is a text format.

The balloon modem codes the NMEA message to the binary format. The relevant data fields were succeeded to compress to the 16 Bytes. The rest three Bytes of the packet are used for transmission of the battery voltage and the microcontroller temperature.

The packet is decoded back to the GGA message format in the ground modem, so the position can be displayed by the common navigation software and standard digital map.

The real data exchange between modems is done via short well-coded packets. The packet structure is in Fig. 5.

Figure 5. Packet structure

\begin{tabular}{|c|c|c|c|}
\hline Preamble & Synchro & Data & CRC \\
64 bits & 16 bits & 152 bits & 16 bits \\
\hline
\end{tabular}

\section{TEST RESUlts}

The parameters of a complete telemetry system are summarized in Tab. II. The realized modems were carefully tested in a laboratory. The setup for sensitivity testing is in Fig. 6. The one modem transmits test packet. The signal is attenuated by the step attenuator and fed to the second modem. The packet error rate was investigated. The test was repeated for the frequency error $+/-2 \mathrm{kHz}$ that corresponds to the maximal expected frequency error caused by the applied TCXO.

TABLE II. TELEMETRY SYSTEM PARAMETERS

\begin{tabular}{|c|c|c|}
\hline Parameter & Value & Note \\
\hline $\begin{array}{l}\text { Rx mode } \\
\text { power } \\
\text { consumption }\end{array}$ & $\begin{array}{l}45 \mathrm{~mA} \\
11,2 \mathrm{~V}\end{array}$ & $\begin{array}{l}\text { Modem + GPS + data logger } \\
+ \text { GPS antenna }\end{array}$ \\
\hline $\begin{array}{l}\text { Tx mode } \\
\text { power } \\
\text { consumption }\end{array}$ & $\begin{array}{l}200 \mathrm{~mA} \\
11,2 \mathrm{~V}\end{array}$ & $\begin{array}{l}\text { Modem + GPS + data logger } \\
+ \text { GPS antenna }\end{array}$ \\
\hline Weight & $205 \mathrm{~g}$ & $\begin{array}{l}44 \mathrm{~g} \text { radiomodem } \\
4 \mathrm{~g} \text { data logger } \\
45 \mathrm{~g} \text { GPS antenna } \\
25 \mathrm{~g} \text { communication antenna } \\
87 \mathrm{~g} \mathrm{LiPol} 11,2 \mathrm{~V} / 1,05 \mathrm{Ah}\end{array}$ \\
\hline $\begin{array}{l}\text { Frequency } \\
\text { error }\end{array}$ & $<1 \mathrm{ppm}$ & $-40 \div+80^{\circ} \mathrm{C}$ \\
\hline Bit rate & $1200 \mathrm{bd}$ & \\
\hline $\begin{array}{l}\text { Packet } \\
\text { length }\end{array}$ & 248 bits & $\begin{array}{l}64 \text { bits preamble } \\
16 \text { bits synchro. word } \\
152 \text { bits data payload } \\
16 \text { bits CRC }\end{array}$ \\
\hline $\begin{array}{l}\text { Packet } \\
\text { duration }\end{array}$ & $207 \mathrm{~ms}$ & \\
\hline Tx power & $25 \mathrm{dBm}$ & \\
\hline $\begin{array}{l}\mathrm{Rx} \\
\text { sensitivity }\end{array}$ & $-124 \mathrm{dBm}$ & $\begin{array}{l}50 \% \text { Packet Error Rate } \\
\text { (PER), +/- } 2 \mathrm{kHz} \text { frequency } \\
\text { offset }\end{array}$ \\
\hline $\begin{array}{l}\text { Ground } \\
\text { antenna gain }\end{array}$ & $10 \mathrm{~dB}$ & Log-Periodic Antenna \\
\hline
\end{tabular}

Figure 6. Sensitivity test setup

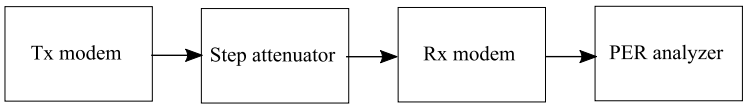

\section{RANGE ESTIMATION}

The estimation of the link budget and range for this to setups is in Tab. III. The implementation losses and propagation loss were critically estimated. Despite this, the telemetry system disposes of the $9 \mathrm{~dB}$ margin that sufficiently guarantees the reliable data reception.

TABLE III. RANGE ESTIMATION

\begin{tabular}{|l|c|c|}
\hline \multicolumn{1}{|c|}{ Parameter } & Tracking station & Search station \\
\hline Tx power & \multicolumn{2}{|c|}{$25 \mathrm{dBm}$} \\
\hline Tx antenna gain & \multicolumn{2}{|c|}{$0 \mathrm{dBi}$} \\
\hline $\begin{array}{l}\text { Tx implementation } \\
\text { losses }\end{array}$ & \multicolumn{2}{|c|}{$3 \mathrm{~dB}$} \\
\hline Maximal range & $200 \mathrm{~km}$ & $100 \mathrm{~km}$ \\
\hline Path loss & $137 \mathrm{~dB}$ & $131 \mathrm{~dB}$ \\
\hline $\begin{array}{l}\text { Propagation losses } \\
\text { in atmosphere }\end{array}$ & $6 \mathrm{~dB}$ & $3 \mathrm{~dB}$ \\
\hline Rx antenna gain & $10 \mathrm{dBi}$ & $0 \mathrm{dBi}$ \\
\hline $\begin{array}{l}\text { Rx implementaion } \\
\text { and polarization } \\
\text { losses }\end{array}$ & $3 \mathrm{~dB}$ & $3 \mathrm{~dB}$ \\
\hline Rx signal level & $-114 \mathrm{dBm}$ & $-115 \mathrm{dBm}$ \\
\hline Rx sensitivity & \multicolumn{2}{|c|}{$-124 \mathrm{dBm}$} \\
\hline Margin & $10 \mathrm{~dB}$ & $9 \mathrm{~dB}$ \\
\hline
\end{tabular}


The range of the telemetry system is estimated under the assumption of usage isotropic $0 \mathrm{dBi}$ antenna in the balloon and $10 \mathrm{dBi}$ antenna used by the tracking team and the $0 \mathrm{dBi}$ antenna used by the search team.

\section{BaLloon Tracking Methodology}

The stratospheric balloon tracking methodology becomes from the experience with the tracking and searching of the FIK balloon mission in December 2015.

The flight trajectory of the balloon can be predicted by some prediction tool, for instance [8]. The predictor uses precise wind forecast. The problem is with the balloon parameters like ascent and descent rate and namely burst altitude that can be estimated only roughly.

The FIK 2 balloon flight will be operated by the launch team, tracking team, and search team. The tracking team will be dislocated on the hill with unlimited view situated in the middle of predicted trajectory. The balloon will be tracked by the directional antenna that will be steered toward the expected balloon position. The purpose of the tracking team is to track balloon during the whole flight above the radio horizon and to navigate search team to the expected landing place.

The same modem equipped with the mobile omnidirectional antenna will be used by the search team for reception of the balloon gondola position after landing or during the last phase of the balloon flight.

The balloon gondola will be equipped with the backup system for position transmission based on the GSM modem. This service is available in the lower altitude as discussed above and according to the FIK 2015 flight experience.

The second backup transmitter will transmit a beacon signal that will be localized by the handheld directional radio finder.

\section{CONCLUSIONS}

The paper presents telemetry system for research stratospheric balloon experiments that study the upper atmosphere and stratosphere parameters. The developed system complies with the predefined requirements. The system was properly tested in the laboratory with the promising results. The balloon flight FIK 2 was realized in $18^{\text {th }}$ March 2017 and verified system performance, as well as the stratospheric balloon tracking and search strategy. The balloon was launched at Pribram airport, climbed to $31400 \mathrm{~m}$ where it burst and returned by parachute. It travelled $168 \mathrm{~km}$ and was successfully tracked by stationary station during whole flight above elevation mask 3 degrees (Fig. 7).
Figure 7. FIK 2 flight track with location of tracking station

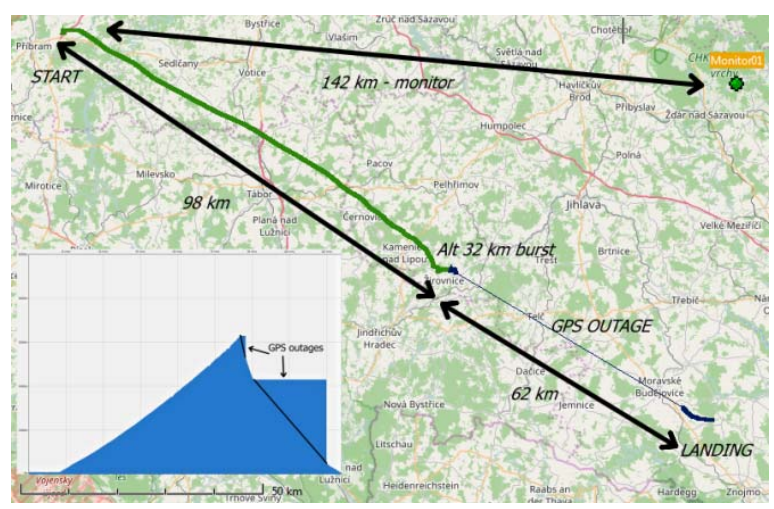

Outages of the position during return flight were caused by interference of GSM module with GPS receiver, but there were observed no message dropouts, the modem just repeated last known position. The system proved successful operation for such kind of telemetry task of reached tracking range about $150 \mathrm{~km}$.

\section{ACKNOWLEDGMENT (HEAdING 5)}

The preparation of this publication was supported by OP RDE, MEYS, Czech Republic under the project CRREAT, CZ.02.1.01/0.0/0.0/15_003/0000481.

\section{REFERENCES}

[1] V. Štěpán, "LET FÍK: Stratosférický balón jako nástroj pro dozimetrii a popularizaci vědy“, In: XXXVIII. Dny radiační ochrany. Praha: České vysoké učení technické v Praze, 2016, pp. 75. ISBN 978-80-01-06028-5.

[2] T. Matsuta, T. Hori and M. Fujimoto, "Optimum directivity of base station antenna in street microcell," 2016 International Symposium on Antennas and Propagation (ISAP), Okinawa, 2016, pp. 458-459.

[3] Chuen-Ching Wang, Ming-Cheng Liang, Nann-Luh Hwang and Shen-Chuan Tai, "Mobile location by time advance for GSM," APMC 2001. 2001 Asia-Pacific Microwave Conference (Cat. No.01TH8577), Taipei, Taiwan, 2001, pp. $882-885$ vol. 2

[4] L. Krupka, L. Vojtech and M. Neruda, "The issue of LPWAN technology coexistence in IoT environment," 2016 17th International Conference on Mechatronics - Mechatronika (ME), Prague, 2016, pp. 1-8.

[5] Lucky 7 [online] SkyFoxLabs, [vid. 2017-03-04], http://www.skyfoxlabs.com/references

[6] ČTU Čj. ČTÚ-12 878/2014-613, všeobecné oprávnění č. VO$\mathrm{R} / 10 / 05.2014-3$ k využívání rádiových kmitočtů a $\mathrm{k}$ provozování zařízení krátkého dosahu, Praha 7. 5. 2014

[7] Si4464/63/61/60 datasheet [online] Silcon Labs, [vid. 201703-04], https://www.silabs.com/documents/public/datasheets/Si4464-63-61-60.pdf.

[8] Balloon flight predictor [online, vid. 2017-03-04], http://predict.habhub.org 